\title{
Distribution of Major and Trace Elements in a Tropical Hydroelectric Reservoir in Sarawak, Malaysia
}

\author{
Siong Fong Sim, Teck Yee Ling, Lee Nyanti, Terri Zhuan Ean Lee, Nurul Aida Lu Mohd \\ Irwan Lu, and Tomy Bakeh
}

Faculty of Resource Science \& Technology, Universiti Malaysia Sarawak, 94300 Kota Samarahan, Sarawak, Malaysia

Correspondence should be addressed to Siong Fong Sim; sfsim@frst.unimas.my

Received 8 April 2014; Revised 8 June 2014; Accepted 8 June 2014; Published 21 September 2014

Academic Editor: Khalid Z. Elwakeel

Copyright (C) 2014 Siong Fong Sim et al. This is an open access article distributed under the Creative Commons Attribution License, which permits unrestricted use, distribution, and reproduction in any medium, provided the original work is properly cited.

\begin{abstract}
This paper reports the metals content in water, sediment, macroalgae, aquatic plant, and fish of Batang Ai Hydroelectric Reservoir in Sarawak, Malaysia. The samples were acid digested and subjected to atomic absorption spectrometry analysis for $\mathrm{Na}, \mathrm{K}, \mathrm{Mn}, \mathrm{Cr}$, $\mathrm{Ni}, \mathrm{Zn}, \mathrm{Mg}, \mathrm{Fe}, \mathrm{Sn}, \mathrm{Al}, \mathrm{Ca}, \mathrm{As}, \mathrm{Se}$, and $\mathrm{Hg}$. The total $\mathrm{Hg}$ content was analysed on the mercury analyser. Results showed that metals in water, sediment, macroalgae, aquatic plant, and fish are distinguishable, with sediment and biota samples more susceptible to metal accumulation. The distributions of heavy metals in water specifically Se, Sn, and As could have associated with the input of fish feed, boating, and construction activities. The accumulation of heavy metals in sediment, macroalgae, and aquatic plant on the other hand might be largely influenced by the redox conditions in the aquatic environment. According to the contamination factor and the geoaccumulation index, sediment in Batang Ai Reservoir possesses low risk of contamination. The average metal contents in sediment and river water are consistently lower than the literature values reported and well below the limit of various guidelines. For fishes, trace element $\mathrm{Hg}$ was detected; however, the concentration was below the permissible level suggested by the Food and Agriculture Organization.
\end{abstract}

\section{Introduction}

Metals contamination has been a concern of hydroelectric development [1-5]. The process inevitably exposes rivers to the risk of metals contamination due to the alteration triggered in hydrological and sediment regime. The trace elements are often released into the aquatic environment from natural and/or anthropogenic sources where they are usually bound to sediment particles or soluble in water. These elements can then be taken up by aquatic organisms and transferred to human via food chain resulting in numerous adverse health effects; for example, methylmercury is a neurotoxin and exposure to arsenic increases the risk of skin cancer [6]. The bioaccumulation factor (BAF), expressed as the ratio of chemical concentrations in organisms over the concentrations in water [7], as high as 150-300 has been reported in fishes such as Tilapia zilli, Tilapia guineensis, Clarias gariepinus, and Synodontis membranaceus for various elements [8-12].
The construction of dam has been long challenged with the issue of elevated mercury $(\mathrm{Hg})$. Upon impoundment of a dam, the naturally occurring inorganic $\mathrm{Hg}$ may be converted to bioavailable organic $\mathrm{Hg}$ by bacteria leading to bioaccumulation of $\mathrm{Hg}$ in fish [13]. The accumulation of $\mathrm{Hg}$ can be very persistent; for example, the methylmercury contamination reported in Canada and Finland took 20-30 years to be restored to the baseline level after impoundment [14]. Besides $\mathrm{Hg}$, other elements were also reported to increase in sediment of Iron Gate, the largest dam and reservoir in Danube, 20 years after impoundment [15]. The potentials of metals contamination in dams and reservoirs have been revealed in numerous studies associating it with various anthropogenic inputs $[16,17]$.

Sarawak, a state in Malaysia on the island of Borneo, possesses high potential for hydroelectric development due to the abundant rainfall throughout the year [18]. A series of hydroelectric projects have been identified of which Batang Ai Hydroelectric Dam is the first dam impounded in 1985. 
The dam is a 29-year-old dam with the reservoir covering a total area of 9,000 ha and a capacity of $100 \mathrm{MW}$. The reservoir has been used for freshwater aquaculture activities where the production increases dramatically over years. In 1993, the production of tilapia fish was estimated at 22.9 metric tonnes (mt), but after 16 years, it increases by 13 -fold to $298.9 \mathrm{mt}$ and further soars to $488.8 \mathrm{mt}$ in 2010 and $744.1 \mathrm{mt}$ in 2011 [19].

According to Roulet et al. [20,21], tropical soil is naturally rich in mercury which tends to be remobilized upon degradation of soil due to deforestation as well as flooding. The release of mercury into the environment due to the hydroelectric dam construction has been repeatedly reported where the element tends to be accumulated in aquatic organisms. The $\mathrm{Hg}$ level in fish of the affected system could take 15-30 years to be restored to its background level [22].

With the continuous increase of demand for aquaculture harvest and the potential of metal contamination particularly the phenomenon of mercury accumulation, the status of Batang Ai Reservoir is poorly understood. There is relatively little information on the metal accumulation in hydroelectric reservoir in this region; Barletta et al. [23] state that river basin and environmental management plans are poorly developed in tropical and subtropical countries. The mercury pollution policies are often not implemented leaving the risk of metal pollution undetermined. Thus, this paper attempts to evaluate the metal pollution status in Batang Ai Reservoir, 29 years after impoundment, reporting the major and trace elements in water, sediment, macroalgae, aquatic plant, and fish.

\section{Materials and Methods}

2.1. Sampling. Water, sediment, macroalgae, aquatic plant, and fish samples were collected from 7 stations in Batang $\mathrm{Ai}$ Reservoir and the Ai River as shown in Figure 1. For water samples, a composite of triplicates was obtained from subsurface, acidified with $5 \mathrm{~mL}$ of $2 \mathrm{M} \mathrm{HNO}_{3}$, and stored at $4^{\circ} \mathrm{C}$. Sediment samples were obtained using a grab sampler, stored in plastic bags, and kept at $4^{\circ} \mathrm{C}$. For biological samples including fish, aquatic plant, and macroalgae, they were representative of the dominant species at respective stations in triplicate. Upon transportation of the samples to the laboratory, they were kept at $-20^{\circ} \mathrm{C}$ until further analysis. Table 1 summarises the species of plant and fish collected. Note that, in this paper, fish samples were only obtained from ST5 near the aquaculture site. Algae and aquatic plant were collected depending on the sample availability.

2.2. Acid Digestion and Metal Analysis. The samples were digested in triplicate and subjected to atomic absorption spectroscopy (AAS) for metal analyses including $\mathrm{Na}, \mathrm{K}, \mathrm{Mn}$, $\mathrm{Cr}, \mathrm{Ni}, \mathrm{Zn}, \mathrm{Mg}, \mathrm{Fe}, \mathrm{Sn}, \mathrm{Al}, \mathrm{Ca}, \mathrm{As}$, and Se. The total $\mathrm{Hg}$ was analysed on a mercury analyser (Perkin Elmer, FIMS 400). The water samples were analysed according to the standard method of APHA [27] where water samples were digested to free elements that are complexed. Samples were first filtered through $0.45 \mu \mathrm{m}$ membrane filter. Approximately $5 \mathrm{~mL}$ of concentrated $\mathrm{HNO}_{3}$ was added to $100 \mathrm{~mL}$ of water sample and put to slow boil on a hotplate to $10-20 \mathrm{~mL}$, until the solution is clear. The sample was left to cool to room temperature and filtered through $0.45 \mu \mathrm{m}$ membrane filter. The filtrate was diluted to $100 \mathrm{~mL}$ for metal analysis.

For biological samples, they were washed under running tap water prior to drying to remove dirt. The dorsal of fish samples was dissected whilst for aquatic plant only the part above ground is considered. The samples were oven dried at $60^{\circ} \mathrm{C}$ and ground. A total of $0.5 \mathrm{~g}$ of sediment sample was digested with $6 \mathrm{~mL}$ of concentrated $\mathrm{HNO}_{3}$ and $2 \mathrm{~mL}$ of $\mathrm{HCl}$ on a hotplate until the solution is colorless. The sample was cooled and filtered through $0.45 \mu \mathrm{m}$ membrane filter and transferred to a $100 \mathrm{~mL}$ volumetric flask where the filtrate was diluted to the mark and mixed. For macroalgae and aquatic plant, $0.5 \mathrm{~g}$ of sample was digested in $6 \mathrm{~mL}$ of concentrated $\mathrm{HNO}_{3}$ whilst for fish $0.25 \mathrm{~g}$ of sample was digested in $6 \mathrm{~mL}$ of $\mathrm{HNO}_{3}$ and $1 \mathrm{~mL}$ of $\mathrm{HCl}$ [28]. All glassware was acid washed.

Detection limits of element analysed were $\mathrm{Na}$ (0.0037 ppm); K (0.0009 ppm); Mn (0.0016 ppm); Cr (0.0054 ppm); $\mathrm{Ni} \quad(0.008 \mathrm{ppm}) ; \mathrm{Zn} \quad(0.0033 \mathrm{ppm}) ; \mathrm{Mg}$ (0.0022 ppm); $\quad \mathrm{Fe} \quad(0.0043 \mathrm{ppm}) ; \quad \mathrm{Sn} \quad(0.21 \mathrm{ppm}) ; \quad \mathrm{Al}$ (0.028 ppm); Ca (0.0037 ppm); As (0.12 ppm); Se (0.23 ppm); and $\mathrm{Hg}$ (at ppb level). Blanks were also analysed for potential contamination.

2.3. Statistical Analysis. The metal contents tabulated in tables with rows corresponding to samples and columns corresponding to variables (elements) were square rooted and standardised prior to principal component analysis (PCA). The multivariate exploratory approach reveals the clustering pattern of various samples and according to sampling locations. This facilitates the interpretation of a relatively large dataset whether metal contents in various samples are distinguishable and whether respective samples can be differentiated according to sampling locations. Pearson's correlation analysis was performed to identify the correlation between two elements where $P$ value at $95 \%$ significance level was computed to evaluate the relationship.

2.4. Assessment of the Contamination Status. The contamination status is evaluated based on the contamination factor $(\mathrm{CF})$, the geoaccumulation index $\left(I_{\text {geo }}\right)$, and the pollution index (PI). The contamination factor is expressed as the concentration of a given element in sediment, $C_{\text {sample }}$, against the value of the average metal in the world surface rock, $C_{\text {background, }}$ stated by Martin and Meybeck [29]. The background levels of various metals are $\mathrm{Mn}(750 \mathrm{mg} / \mathrm{kg}), \mathrm{Cr}$ (71 mg/kg), Ni (49 mg/kg), Zn (127 mg/kg), Mn (750 mg/kg), $\mathrm{Hg}(0.4 \mathrm{mg} / \mathrm{kg})$, and Fe $(35900 \mathrm{mg} / \mathrm{kg})$. For CF $<1$, the level of contamination is interpreted as low whilst $1 \leq \mathrm{CF} \leq 3$ is moderately contaminated, $3 \leq \mathrm{CF} \leq 6$ is contaminated, and $\mathrm{CF}>6$ is highly contaminated. Consider the following:

$$
\mathrm{CF}=\frac{C_{\text {sample }}}{C_{\text {background }}} .
$$

The geoaccumulation index, $I_{\text {geo }}$, is calculated to illustrate the enrichment of metal concentration above the baseline concentrations [30]. According to Muller's classification, the 


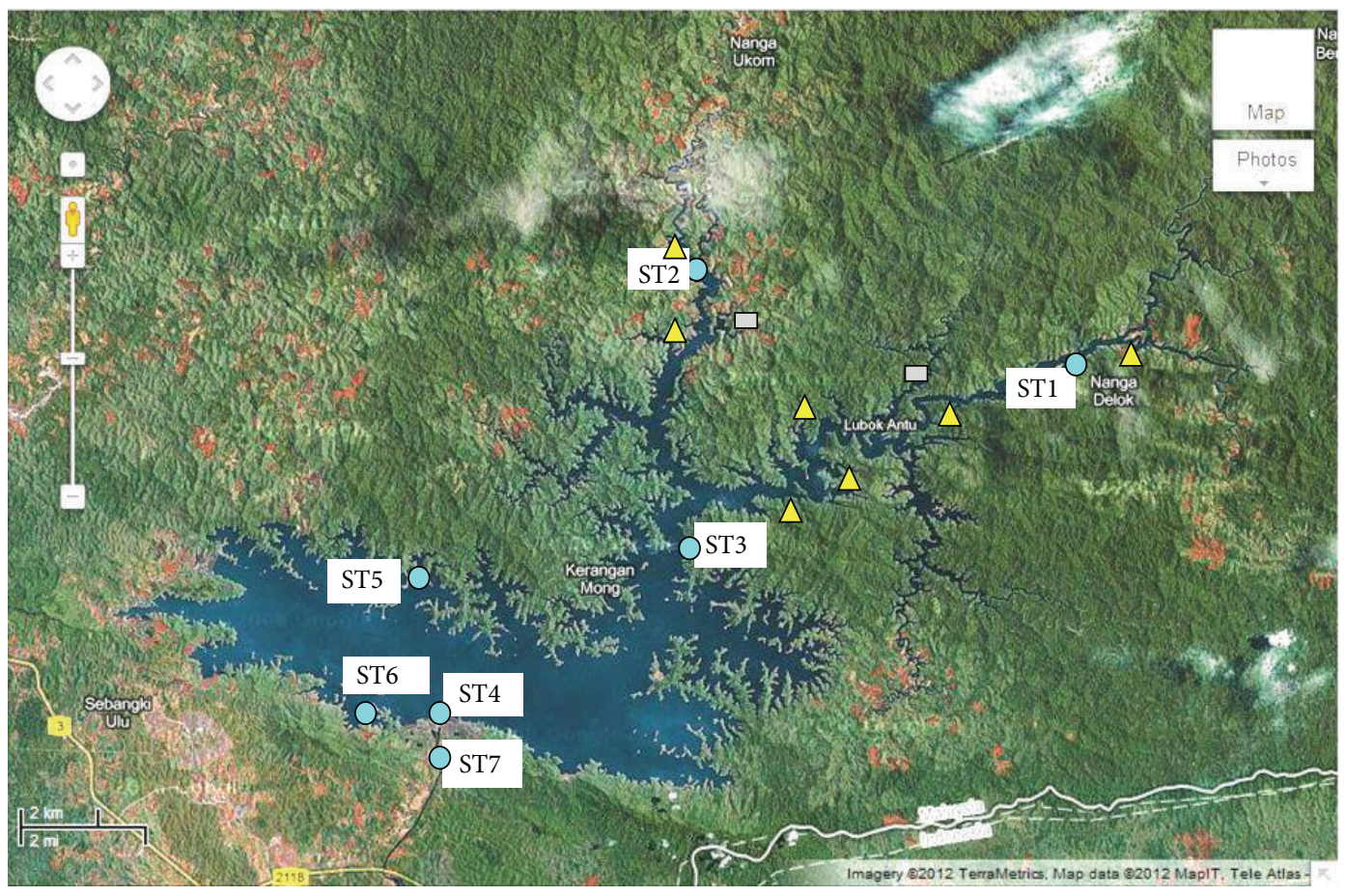
Sampling stations
$\triangle$ Long houses
$\square$ School

Figure 1: The sampling locations at Batang Ai Reservoir and the Ai River.

TABLE 1: Summary of species of macroalgae, aquatic plant, and fish samples.

\begin{tabular}{|c|c|c|c|}
\hline Fish (total length $(\mathrm{cm}))$ & Description & Algae/aquatic plants & Description \\
\hline $\begin{array}{l}\text { Barbonymus schwanenfeldii } \\
(33.4 \mathrm{~cm})\end{array}$ & $\begin{array}{l}\text { It is largely herbivorous, consuming aquatic } \\
\text { macrophytes and submerged plants as well as algae. }\end{array}$ & Enteromorpha sp. & $\begin{array}{c}\text { Found at ST1. It is } \\
\text { commonly known as } \\
\text { macroalgae. }\end{array}$ \\
\hline $\begin{array}{l}\text { Hampala macrolepidota } \\
(19.0 \mathrm{~cm})\end{array}$ & $\begin{array}{l}\text { It is a migratory species where the diet consists } \\
\text { mainly of aquatic insects. }\end{array}$ & Polygonum sp. & $\begin{array}{l}\text { Found at ST6. It is a type of } \\
\text { floating aquatic plant. }\end{array}$ \\
\hline $\begin{array}{l}\text { Cyclocheilichthys apogon } \\
(17.7 \mathrm{~cm})\end{array}$ & $\begin{array}{l}\text { It is a carnivorous species consuming mainly small } \\
\text { fish and aquatic insects. }\end{array}$ & Fimbristylis globulosa & $\begin{array}{l}\text { Found at ST7. It is an } \\
\text { emergent aquatic plant. }\end{array}$ \\
\hline $\begin{array}{l}\text { Hemibagrus planiceps } \\
(21.4 \mathrm{~cm})\end{array}$ & $\begin{array}{l}\text { It is probably a predator feeding on crustaceans and } \\
\text { smaller fishes. }\end{array}$ & & \\
\hline $\begin{array}{l}\text { Barbonymus collingwoodii } \\
(18.6 \mathrm{~cm})\end{array}$ & $\begin{array}{l}\text { It is largely herbivorous, consuming aquatic } \\
\text { macrophytes and submerged plants as well as algae. }\end{array}$ & & \\
\hline
\end{tabular}

sediment is classified as unpolluted if $I_{\text {geo }}<0$, progressing from unpolluted to moderately polluted if $I_{\text {geo }}$ is between 0 and 1, moderately polluted if $I_{\text {geo }}$ is between 1 and 2, moving into polluted if $I_{\text {geo }}$ is between 2 and 3, and polluted if $I_{\text {geo }}$ is between 3 and 4 . Consider the following:

$$
I_{\text {geo }}=\log _{2}\left(\frac{C_{\text {sample }}}{1.5 * C_{\text {background }}}\right) .
$$

The pollution load index (PLI) is calculated as $\left(\mathrm{CF}_{1} \times \mathrm{CF}_{2} \times \mathrm{CF}_{3} \times \cdots \mathrm{CF}_{n}\right)^{1 / n}$, where $n$ is the number of metals. The PLI value of $>1$ suggests the sediment is polluted whilst PLI $<0$ implies unpolluted [31].

\section{Results and Discussion}

3.1. The Distribution of Heavy Metals in Water, Sediment, Aquatic Plant, Macroalgae, and Fish. Metals in water, sediment, macroalgae, aquatic plant, and fish are subjected to PCA yielding a scores plot of PC2 versus PC1 in Figure 2(a) with a total variance of $55.95 \%$. The corresponding loadings plot is shown in Figure 2(b). Clearly, the distributions of metals in different samples are distinguishable where the loadings plot suggests that $\mathrm{Hg}$ and As are characteristic of water while $\mathrm{Na}$ is typical to fish. Table 2 summarises the nonzero average of metal contents in respective samples. Essentially, elements such as $\mathrm{Ca}, \mathrm{Mg}$, and $\mathrm{K}$ are more 


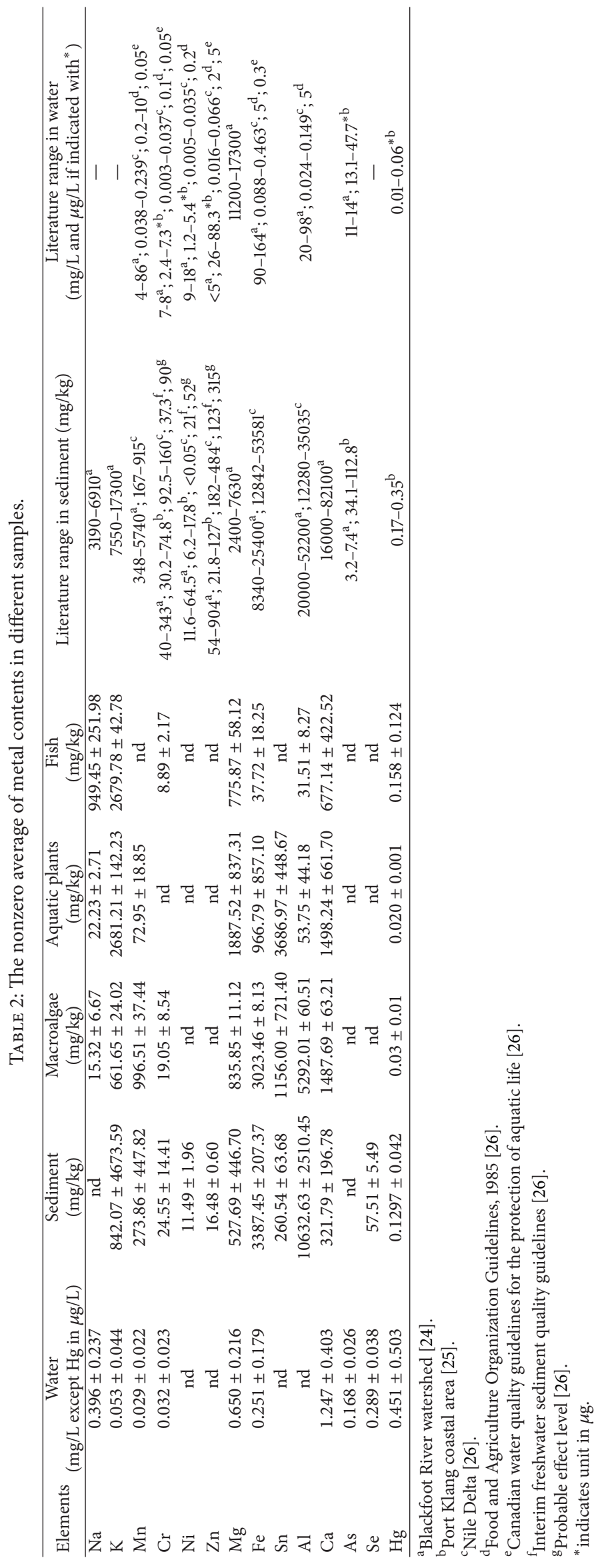




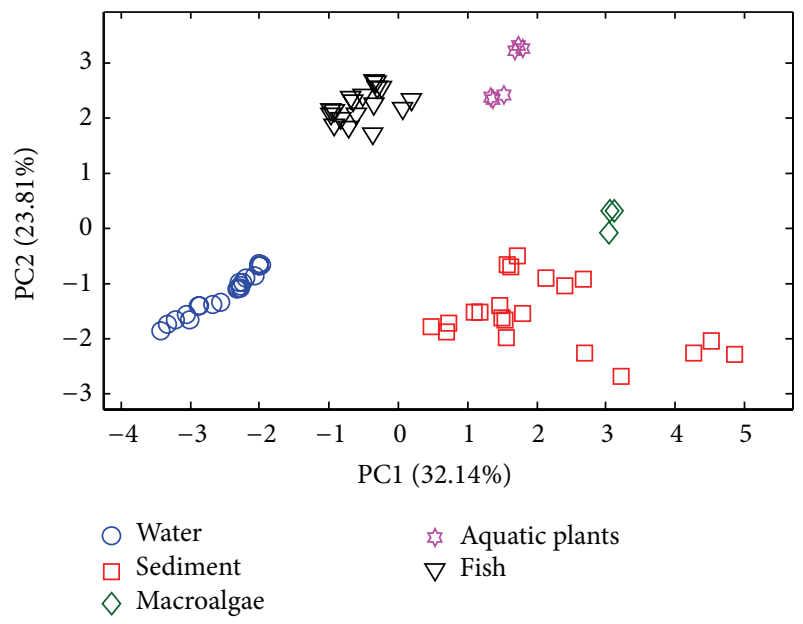

(a)

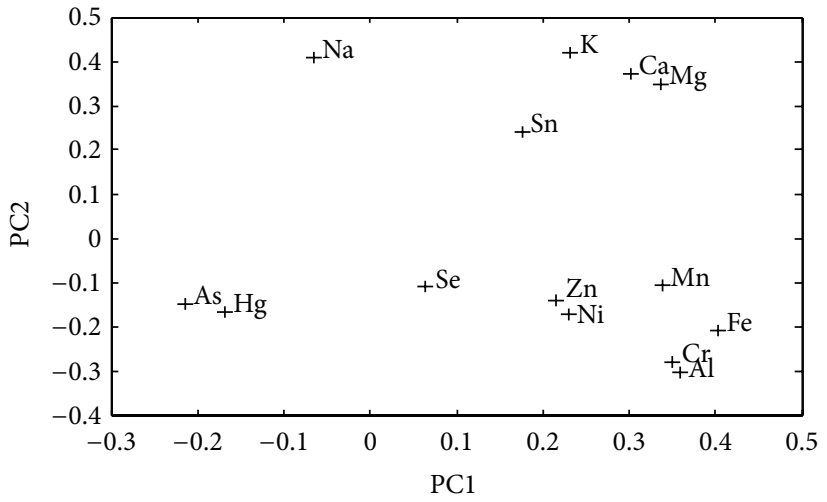

(b)

FIGURE 2: The scores plot of heavy metal contents according to heavy metals in water, sediment, aquatic plant, macroalgae, and fish.

prominent in sediment, macroalgae, aquatic plant, and fish with $\mathrm{Na}$ present in appreciable amount in fish. Aluminium on the other hand is profoundly detected in sediment due to the high content of silicoaluminate clays; nevertheless it is unlikely to be found in biological samples as $\mathrm{Al}$ in this form is insoluble. Under acidic condition, it may become more soluble and thus more available for plant uptake [32]. Other elements such as $\mathrm{Fe}, \mathrm{Mn}$, and $\mathrm{Cr}$ are variably detected in various samples, that is, sediment, macroalgae, aquatic plant, and fish, with Sn prominently present in macroalgae and plants. As a whole, metals tend to be found in higher concentrations in sediment corroborating its nature as metal bioaccumulators. The average trace metal contents specifically $\mathrm{As}, \mathrm{Cr}, \mathrm{Ni}$, and $\mathrm{Zn}$ in sediment are relatively lower than those reported in a canyon reservoir in Southwest China [33]. They are also lower than those found in the hydroelectric dam of Danube [34]. In comparison to the selected metals, namely, $\mathrm{Al}, \mathrm{Zn}$, and Fe, identified in fishes of Tasik Mutiara, Malaysia, fishes at Batang Ai Reservoir are characterised by lower concentrations with As similarly undetected [35]. The level of $\mathrm{Hg}$ in fish on the other hand ranges between 0.03 and $0.20 \mathrm{mg} / \mathrm{kg}$, comparatively lower than the range reported elsewhere, for example, in Tucuruí Reservoir and River Mojú (0.11-1.3 mg/kg) [36]; Newfoundland $(0.13-0.86 \mathrm{mg} / \mathrm{kg})$ [37]; Tanzania $(0.003-0.263 \mathrm{mg} / \mathrm{kg})$ [38]; Guizhou (0.3-0.5 mg/kg) [39]. Likewise Hg in sediment, at an average of $0.129 \mathrm{mg} / \mathrm{kg}$, is less prominent than the level reported in two hydroelectric reservoirs in Quebec, Canada $(0.15-0.49 \mathrm{mg} / \mathrm{kg})$ [40]. Tin is found in elevated concentration in macroalgae and aquatic plants; according to Thompson et al. [41], the bioaccumulation factor of Sn in these samples can be as high as 100 where Nirbadha et al. [42] likewise revealed relatively large quantities of $\mathrm{Sn}$ in three aquatic plants in Kelaniya.

The occurrence of metals in water, sediment, macroalgae, aquatic plant, and fish is examined independently with PCA; the scores plots are shown in Figure 3 according to sampling stations. For surface water, it appears that samples from the
Ai River (ST1, ST3, ST4, and ST7) are primarily distributed over the upper region of the scores plot whilst samples from the aquaculture sites (ST5 and ST6 (abandoned)) are scattered around the lower right. The underlying pattern of metal distributions in sediment on the other hand suggests that samples from the upper stream (ST1), near the outflow (ST4), and downstream of the power house (ST7) are distinguishable. Macroalgae and aquatic plants collected from three different stations are seemingly differentiable. For fish, no distinctive pattern is interpretable. Figure 4 illustrates the average metal concentrations in various samples according to sampling stations where the error bars indicate the standard deviations.

Evidently, Se is below the detection limit in most water samples except ST5 and ST6 with aquaculture activities. The presence of Se can be an indication of excessive discharge of fish feed as Se has been commonly added to animal feed including fish meal due to its importance in biological function $[43,44]$. This element was consistently detected in fish feed by Alam et al. [45], Maule et al. [46], and Ikem and Egilla [44] at average concentrations of $5.4 \mathrm{mg} / \mathrm{kg}$, $2.48 \mathrm{mg} / \mathrm{kg}$, and $1.7 \mathrm{mg} / \mathrm{kg}$, respectively. Ikem and Egilla [44] further examined the level of Se present correspondingly in aquaculture fish muscles with concentration ranges $0.2-$ $0.4 \mathrm{mg} / \mathrm{kg}$. As a whole, no significant correlation can be deduced between the waterborne and the accumulated Se in sediment. According to Canton and Derveer [47], the accumulation of Se in sediment does not correspond very well to the waterborne Se. It depends largely on the redox conditions where, under strongly reduced environment, insoluble selenium usually predominates [48]. As observed, Se is found in sediment at ST3 whilst the bioaccumulation of Se in aquatic plants is negligible.

Arsenic is detected in water at ST3, ST4, and ST7. This may be associated with the development and construction activity nearby as studies revealed that As is susceptible to leaching from construction debris with chromate-copperarsenate (CCA) wood $[49,50]$. At ST3, there are several long 


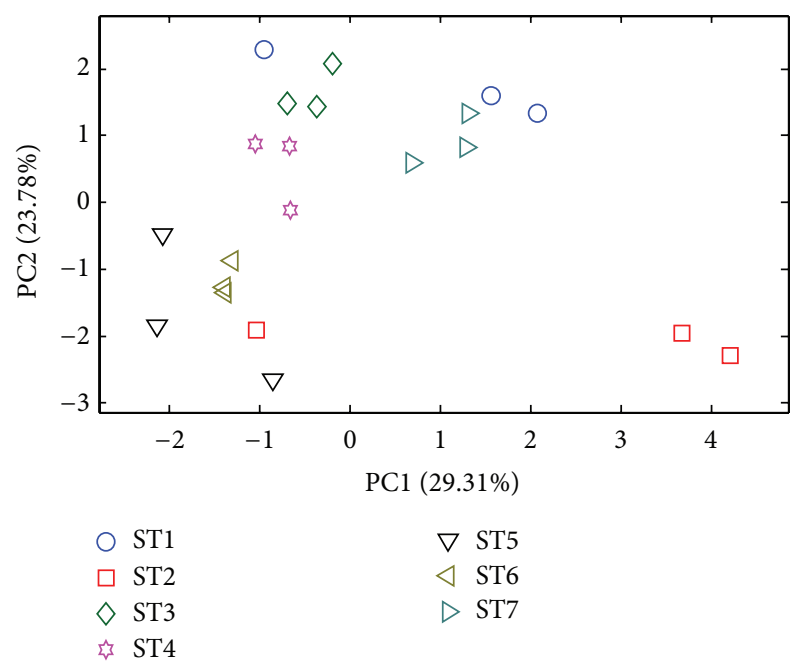

(a) Water

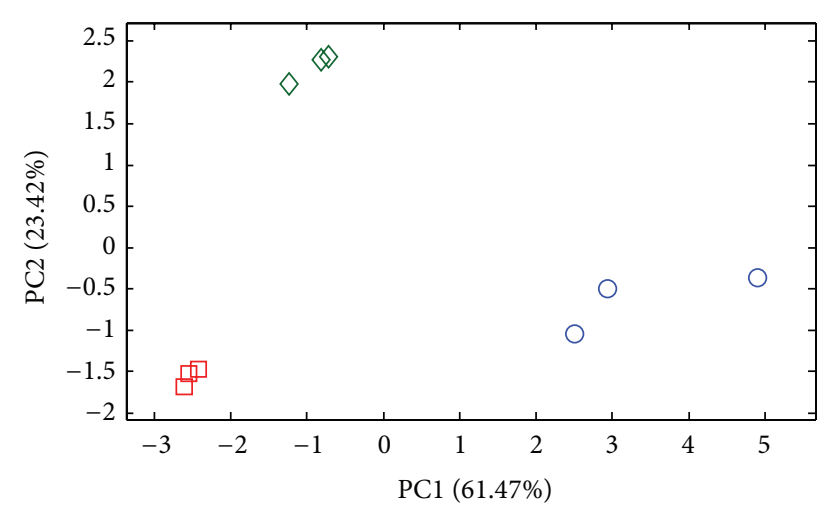

(c) Macroalgae and aquatic plant

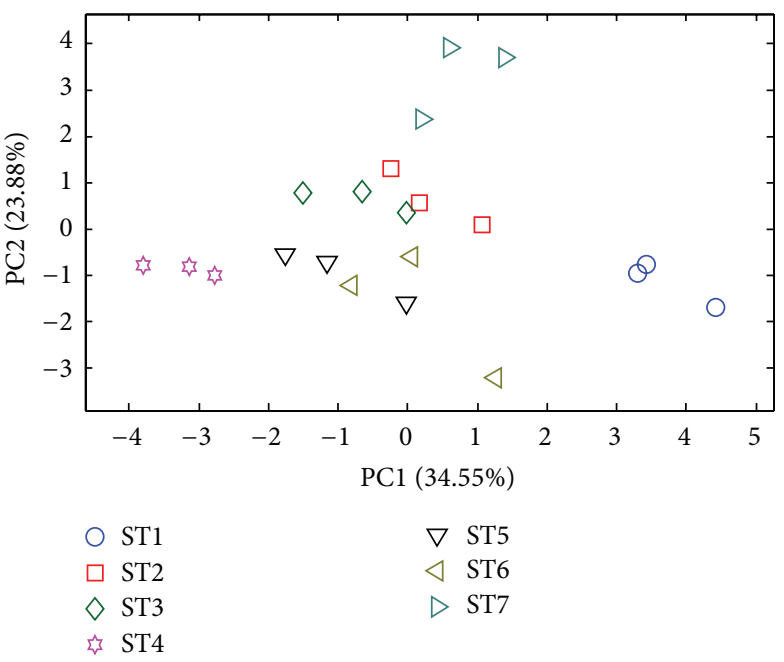

(b) Sediment

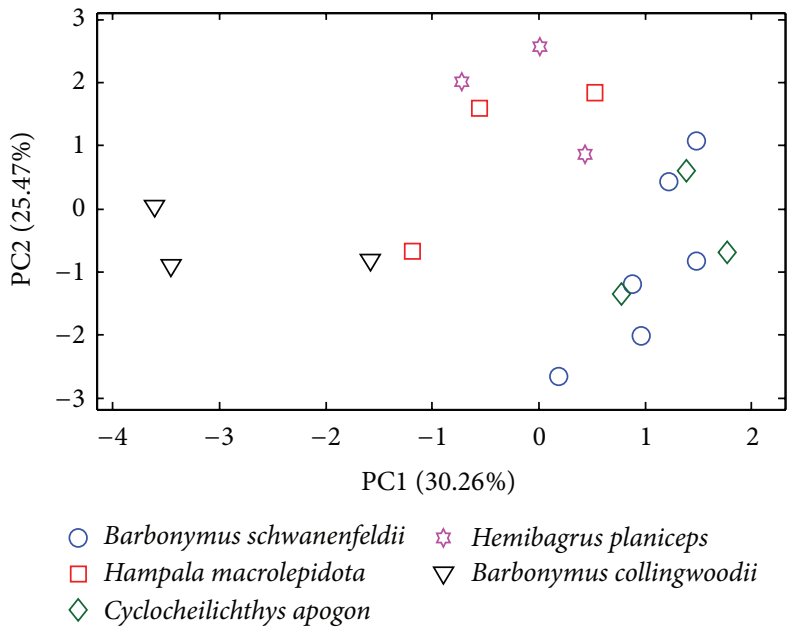

(d) Fish

FIGURE 3: The scores plot of heavy metals in water, sediment, macroalgae, aquatic plant, and fish according to sampling stations.

houses and a resort is located $4 \mathrm{~km}$ south of ST3, ST4 is near the outflow, and ST7 is downstream of the power house. Despite the presence of As in several stations, the element is undetected in other corresponding samples. Mn and Fe are found distinctively in water samples at ST1, ST2, and ST7. These elements are naturally present in soils; under reduced conditions, they tend to exist in soluble forms resulting in increased concentrations in water [51]. The distribution patterns of $\mathrm{Mn}$ and $\mathrm{Fe}$ in water are very similar with a correlation coefficient of 0.93 suggesting that both elements are geochemically correlated. Naturally, they are constituents of various source rocks, that is, igneous rock; in addition, they possess similar dissolution and precipitation behaviour under comparable redox conditions.

Sn, particularly organotin, has been widely used as a component in antifouling paint, applied as a finish coat to the submerged part of boat, and in pesticides. In this study, Sn is found in an appreciable amount in algae and plants. In fact, $\mathrm{Sn}$ is relatively immobile; it may exist as $\mathrm{Sn}(\mathrm{II})$ or $\mathrm{Sn}(\mathrm{IV})$ where both forms are readily precipitated under reduced conditions. The element can be profoundly accumulated in aquatic organisms. According to Thompson et al. [41], the bioaccumulation factors of tin in freshwater plant and fish could be as high as 100 and 3000, respectively. The present results likewise suggest that algae and aquatic plants are good indicators of Sn accumulation; its distribution is markedly higher near the aquaculture site (ST6) and the downstream of power station (ST7) possibly due to boating activities as well as the cooling system where tributyltin is commonly used in biocides. To date, there is no legislation in Malaysia to control the use of tributyltin. In this study, $\mathrm{Cr}$ is present at an average of $20 \mathrm{mg} / \mathrm{kg}$ in sediment of almost all stations except ST6 where higher concentration is also found in water. Despite the elevated concentration of $\mathrm{Cr}$ at ST6, there is no sign of bioaccumulation in the aquatic plants indicating that the element may not be bioavailable. 

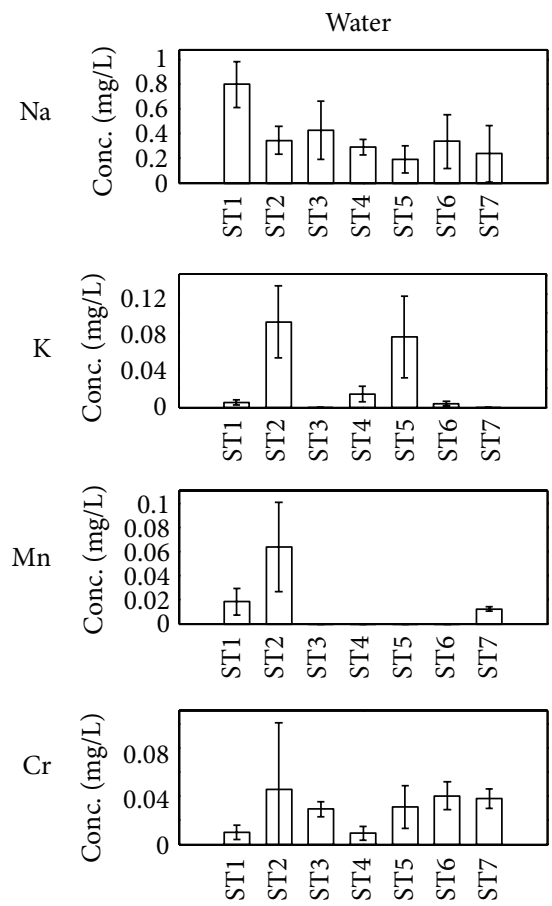

$\mathrm{Ni}$

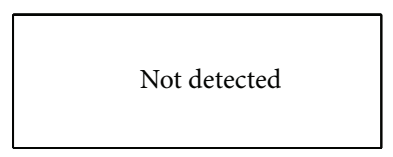

$\mathrm{Zn}$
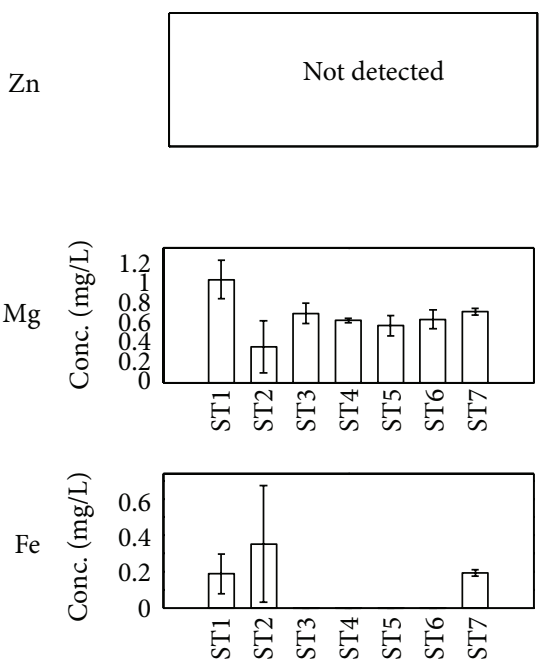

Sn

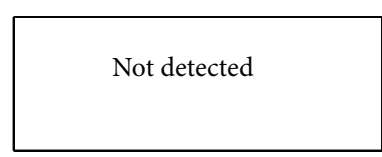

$\mathrm{Al}$

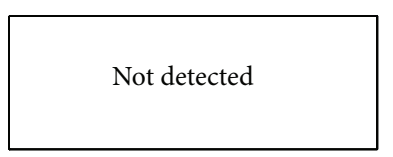

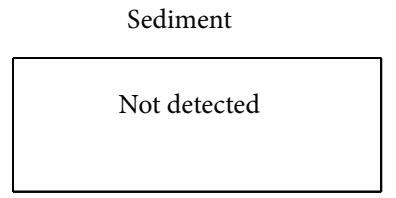
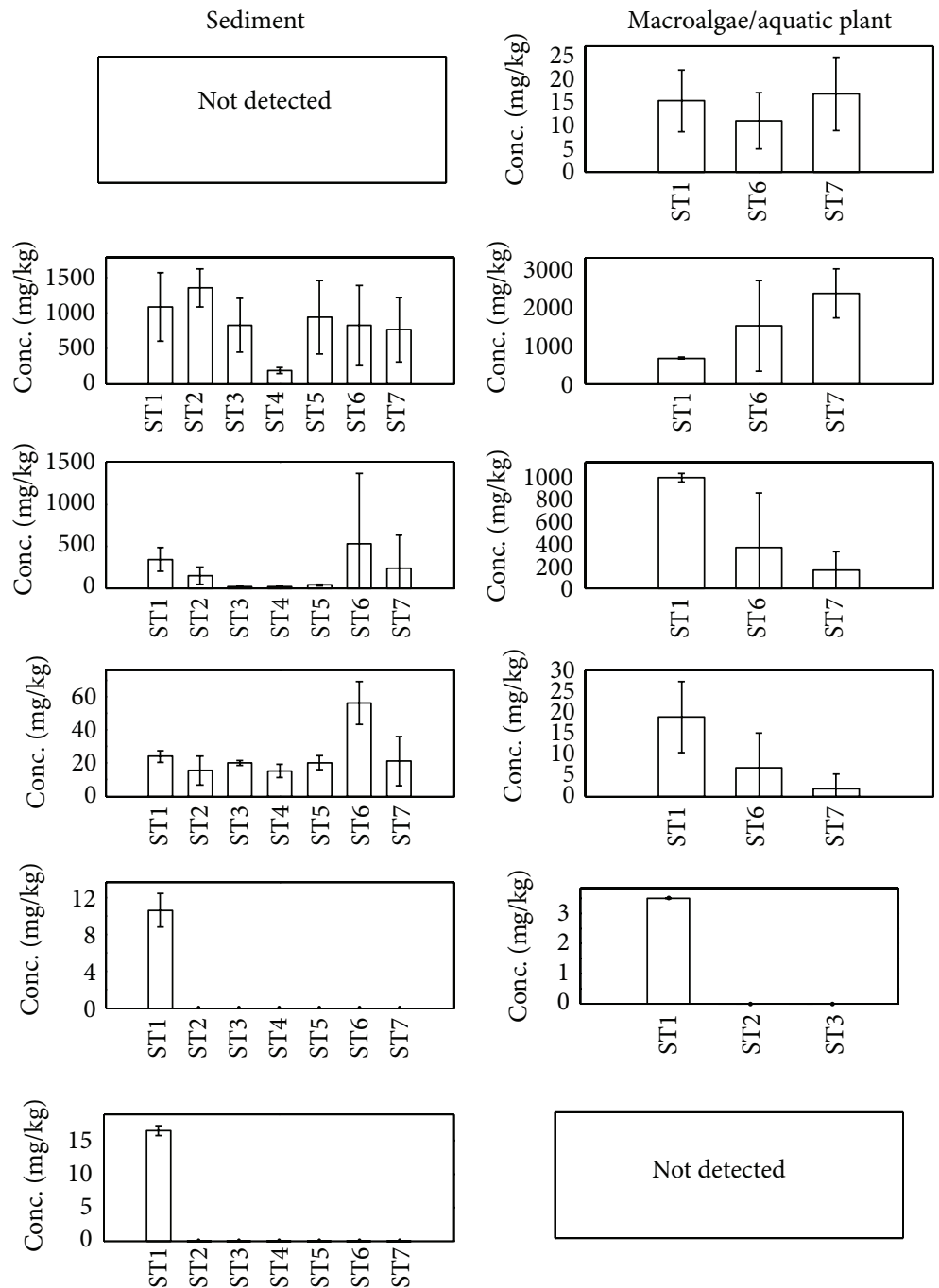

Not detected
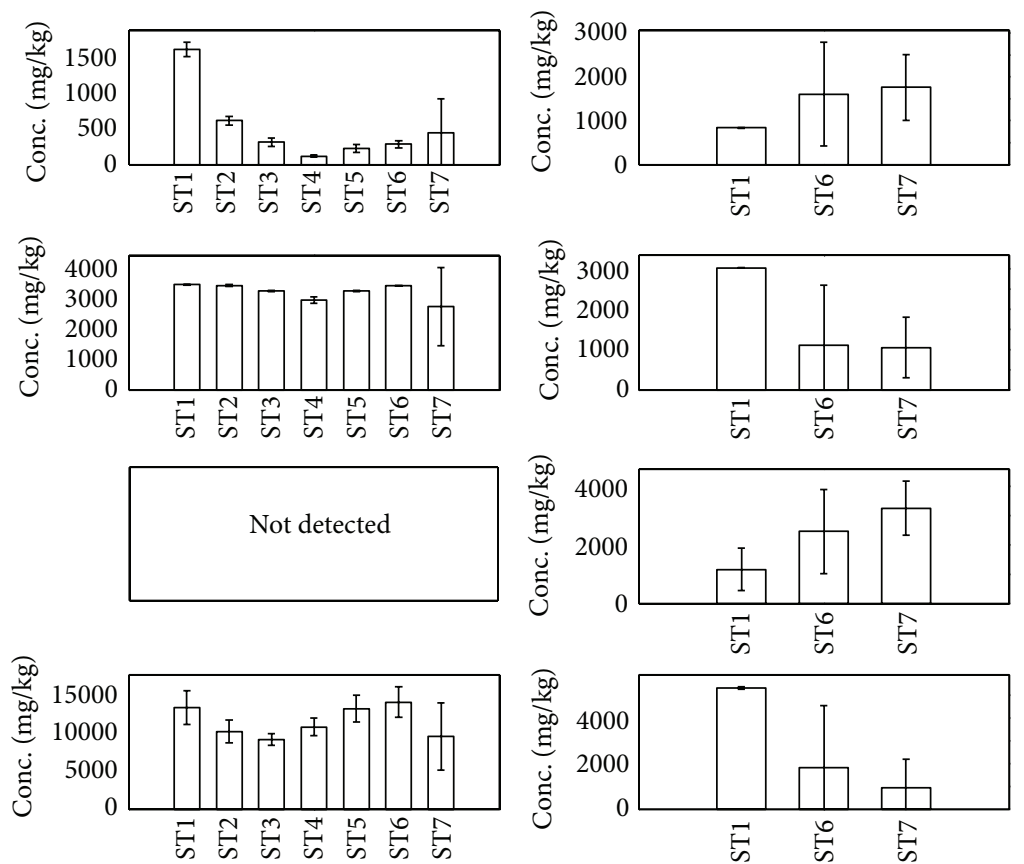

Figure 4: Continued. 

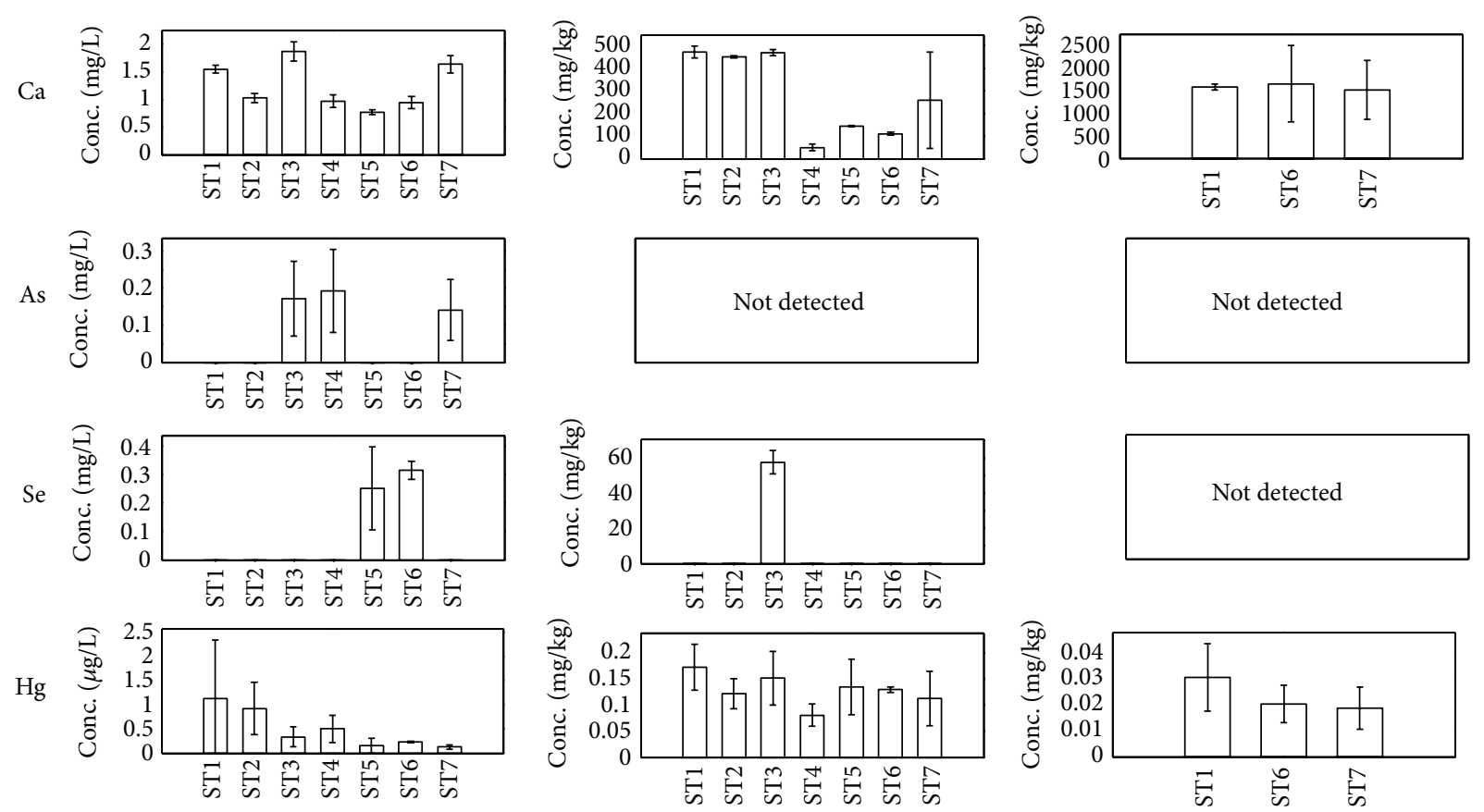

FIGURE 4: The average metal contents in water, sediment, macroalgae, and aquatic plant according to sampling stations.
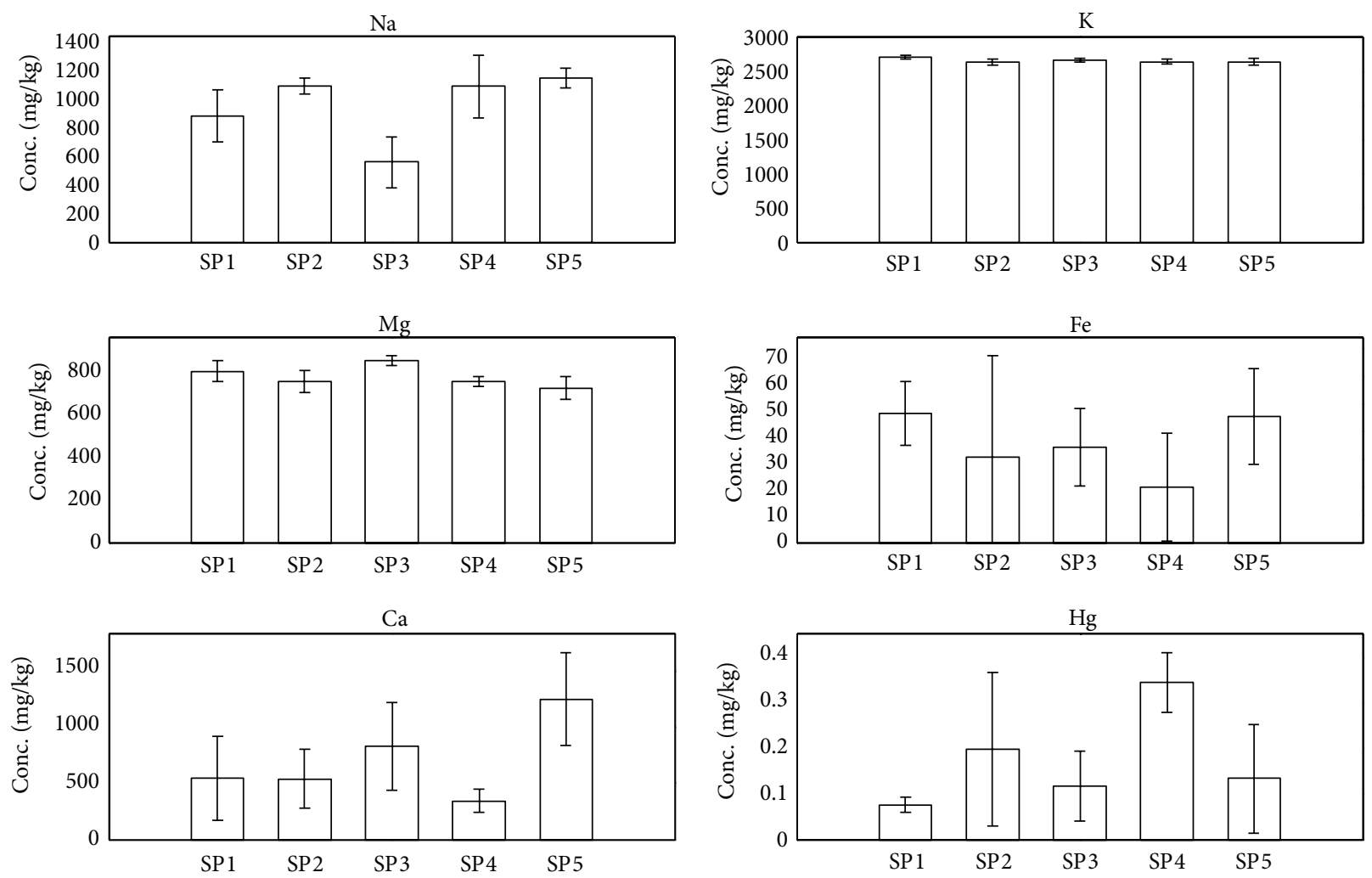

FIGURE 5: The average concentrations of six prominent elements in fish according to species and parts (SP1: Barbonymus schwanenfeldii; SP2: Hampala macrolepidota; SP3: Cyclocheilichthys apogon; SP4: Hemibagrus planiceps; SP5: Barbonymus collingwoodii). 
TABLE 3: Correlation analysis of metal concentrations in (a) water, (b) sediment, and (c) macroalgae and aquatic plant.

(a) Water

\begin{tabular}{|c|c|c|c|c|c|c|c|c|c|c|}
\hline & $\mathrm{Na}$ & $\mathrm{K}$ & $\mathrm{Mn}$ & $\mathrm{Cr}$ & $\mathrm{Mg}$ & $\mathrm{Fe}$ & $\mathrm{Ca}$ & As & $\mathrm{Se}$ & $\mathrm{Hg}$ \\
\hline $\mathrm{Na}$ & 1.00 & & & & & & & & & \\
\hline $\mathrm{K}$ & -0.34 & 1.00 & & & & & & & & \\
\hline $\mathrm{Mn}$ & 0.15 & 0.61 & 1.00 & & & & & & & \\
\hline $\mathrm{Cr}$ & -0.51 & 0.39 & 0.40 & 1.00 & & & & & & \\
\hline $\mathrm{Mg}$ & 0.75 & -0.71 & -0.42 & -0.65 & 1.00 & & & & & \\
\hline $\mathrm{Fe}$ & 0.25 & 0.40 & 0.93 & 0.32 & -0.16 & 1.00 & & & & \\
\hline $\mathrm{Ca}$ & 0.46 & -0.61 & -0.07 & -0.12 & 0.55 & 0.14 & 1.00 & & & \\
\hline As & -0.24 & -0.51 & -0.40 & -0.32 & 0.05 & -0.33 & 0.46 & 1.00 & & \\
\hline $\mathrm{Se}$ & -0.35 & 0.15 & -0.39 & 0.34 & -0.18 & -0.50 & -0.62 & -0.54 & 1.00 & \\
\hline $\mathrm{Hg}$ & 0.78 & 0.19 & 0.64 & -0.36 & 0.25 & 0.62 & 0.10 & -0.34 & -0.50 & 1.00 \\
\hline
\end{tabular}

(b) Sediment

\begin{tabular}{|c|c|c|c|c|c|c|c|c|c|c|c|}
\hline & $\mathrm{K}$ & $\mathrm{Mn}$ & $\mathrm{Cr}$ & $\mathrm{Ni}$ & $\mathrm{Zn}$ & $\mathrm{Mg}$ & $\mathrm{Fe}$ & $\mathrm{Al}$ & $\mathrm{Ca}$ & $\mathrm{Se}$ & $\mathrm{Hg}$ \\
\hline $\mathrm{K}$ & 1.00 & & & & & & & & & & \\
\hline $\mathrm{Mn}$ & 0.25 & 1.00 & & & & & & & & & \\
\hline $\mathrm{Cr}$ & 0.02 & $0.84^{*}$ & 1.00 & & & & & & & & \\
\hline $\mathrm{Ni}$ & 0.28 & 0.35 & -0.02 & 1.00 & & & & & & & \\
\hline $\mathrm{Zn}$ & 0.28 & 0.35 & -0.02 & 1.00 & 1.00 & & & & & & \\
\hline $\mathrm{Mg}$ & 0.51 & 0.39 & -0.06 & $0.95^{*}$ & $0.95^{*}$ & 1.00 & & & & & \\
\hline $\mathrm{Fe}$ & 0.64 & 0.34 & 0.35 & 0.39 & 0.39 & 0.43 & 1.00 & & & & \\
\hline $\mathrm{Al}$ & 0.13 & 0.58 & 0.62 & 0.41 & 0.41 & 0.28 & 0.55 & 1.00 & & & \\
\hline $\mathrm{Ca}$ & 0.70 & -0.04 & -0.32 & 0.46 & 0.46 & 0.64 & 0.39 & -0.34 & 1.00 & & \\
\hline $\mathrm{Se}$ & -0.03 & -0.39 & -0.14 & -0.17 & -0.17 & -0.18 & 0.05 & -0.51 & 0.45 & 1.00 & \\
\hline $\mathrm{Hg}$ & 0.64 & 0.29 & 0.17 & 0.66 & 0.66 & 0.68 & 0.63 & 0.32 & 0.68 & 0.34 & 1.00 \\
\hline
\end{tabular}

(c) Aquatic plants and macroalgae

\begin{tabular}{|c|c|c|c|c|c|c|c|c|}
\hline & $\mathrm{Na}$ & $\mathrm{K}$ & $\mathrm{Cr}$ & $\mathrm{Mg}$ & $\mathrm{Fe}$ & $\mathrm{Al}$ & $\mathrm{Ca}$ & $\mathrm{Hg}$ \\
\hline $\mathrm{Na}$ & 1.00 & & & & & & & \\
\hline $\mathrm{K}$ & -0.47 & 1.00 & & & & & & \\
\hline $\mathrm{Cr}$ & 0.14 & 0.59 & 1.00 & & & & & \\
\hline $\mathrm{Mg}$ & $-0.93^{*}$ & 0.61 & 0.20 & 1.00 & & & & \\
\hline $\mathrm{Fe}$ & -0.29 & 0.68 & 0.10 & 0.18 & 1.00 & & & \\
\hline $\mathrm{Al}$ & 0.43 & -0.38 & -0.20 & -0.62 & 0.24 & 1.00 & & \\
\hline $\mathrm{Ca}$ & 0.13 & -0.23 & 0.07 & -0.21 & 0.17 & $0.83^{*}$ & 1.00 & \\
\hline $\mathrm{Hg}$ & 0.43 & -0.70 & -0.44 & -0.46 & -0.79 & -0.11 & -0.41 & 1.00 \\
\hline
\end{tabular}

For other elements such as $\mathrm{Ni}, \mathrm{Zn}$, and $\mathrm{Mg}$, there is no concern of heavy metal contamination but interestingly they are detected distinctively in sediment at ST1 upstream.

Five species of fish samples were collected from the reservoir near the aquaculture farm at ST5. No well-defined separation can be interpreted based on the scores plot of PCA. Figure 5 shows the average concentrations of six prominent elements according to species. Obviously, $\mathrm{Hg}$ seems to be bioaccumulated in higher concentration in Hampala macrolepidota and Hemibagrus planiceps; nevertheless the amount is generally well below the permissible level set by FAO at $0.5 \mathrm{mg} / \mathrm{kg}$ suggesting that the selected fishes are safe for consumption [52]. Other predominating elements are primarily major elements such as $\mathrm{Na}$ and $\mathrm{K}$.
3.2. Correlation of Metals. The relationships of metals within samples, that is, water, sediment, and macroalgae/aquatic plant, are correlated based on the mean concentrations. Table 3 summarises the results of Pearson's correlation analysis, where $P<0.05$ are highlighted. The findings suggest that $\mathrm{Mn}$ and $\mathrm{Fe}$ in water are positively correlated whilst $\mathrm{Na}$ and $\mathrm{Hg}$ also demonstrate significant correlation. In sediment, on the other hand, positive correlations are statistically confirmed in $\mathrm{Zn}-\mathrm{Ni}-\mathrm{Mg}$ and Fe-Mn. For macroalgae/aquatic plants, Na$\mathrm{Mg}$ are negatively correlated whilst $\mathrm{Ca}-\mathrm{Al}$ correlate positively. The negative correlation, as suggested by Osaki et al. [53], indicates antagonistic mechanism in metal accumulation whereas positive correlation could imply that elements are taken via similar mechanisms. The correlations of metals 
between samples, that is, water-sediment, water-plant, and sediment-plant, are also evaluated. Apparently, no significant correlation is statistically deduced except $\mathrm{Hg}$ in water-plant $(r=0.99)$ and $\mathrm{Ni}$ in sediment-plant $(r=1)$.

Considering the metals uptake in algae and plant, macroalgae at ST1 demonstrates greater tendency of metal accumulation. According to Michalak and Chojnacka [54], macroalgae exhibits greater ability in accumulating heavy metals (more than 10 times) than vascular plants whilst studies elsewhere further support that Enteromorpha sp. is an excellent indicator for a wide range of metals including $\mathrm{Fe}, \mathrm{Al}$, $\mathrm{Mn}, \mathrm{Ni}$, and $\mathrm{Zn}$ [55-57]. The other plants species, Polygonum sp. and Fimbristylis globulosa at ST6 and ST7, respectively, are also possible metals accumulators; they have been employed for phytoremediation, treating water polluted with $\mathrm{Cu}, \mathrm{Cd}$, $\mathrm{Zn}$, and $\mathrm{Pb}[58]$.

3.3. Assessment of Contamination Status. The contamination factors (CF) calculated for $\mathrm{Mn}, \mathrm{Cr}, \mathrm{Ni}, \mathrm{Zn}, \mathrm{Mn}$, and Fe are comfortably below 1 . The $\mathrm{CF}$ of $\mathrm{Hg}$, however, is slightly above 0 , at an average of 0.322 , indicative of slight pollution. According to a survey of $\mathrm{Hg}$ present in 73 rivers of the USA, the concentrations reported range between $0.1 \mu \mathrm{g} / \mathrm{L}$ and $5 \mu \mathrm{g} / \mathrm{L}$ with two rivers exceeding $5 \mu \mathrm{g} / \mathrm{L}$ (the limit for potable water supplies according to the Public Health Service) [59]. The unpolluted $\mathrm{Hg}$ level is defined at $<0.1 \mu \mathrm{g} / \mathrm{L}$; with this criterion, the average $\mathrm{Hg}$ detected in the reservoir of $0.451 \mu \mathrm{g} / \mathrm{L}$ is suspected to be affected by the anthropogenic inputs. Nonetheless, the concentration accumulated in the sediment, at an average of $0.129 \mathrm{mg} / \mathrm{kg}$, is below the limit of $1 \mathrm{mg} / \mathrm{kg}$ set in sediment for attention [59]. The geoaccumulation indices, $I_{\text {geo }}$, are less than 0 for all elements considered; according to Muller's classification, the sediment is categorised as unpolluted. The pollution load indices calculated across all stations (PLI) are consistently less than 1 suggesting no risk of contamination at the moment. The average metal concentrations in sediment and river water (as summarised in Table 1) are consistently lower than the literature values and are well below the limit set according to various guidelines such as the Food and Agriculture Organization Guidelines, 1985, Canadian water quality guidelines for the protection of aquatic life, interim freshwater sediment quality guidelines, and the probable effect level [24-26].

\section{Conclusions}

The findings of the study indicate that there is low risk of heavy metal contamination in the environment of Batang Ai Hydroelectric Reservoir. The aquaculture and development activities, however, may result in elevated Se, As, and Sn. The availability of the trace elements is largely governed by the redox conditions in the environment. Generally, there is no special concern of heavy metal contamination in fish; nonetheless there is a tendency of $\mathrm{Hg}$ bioaccumulation and continuous monitoring is necessary.

\section{Conflict of Interests}

The authors declare that there is no conflict of interests regarding the publication of this paper.

\section{Acknowledgments}

The authors would like to thank the Ministry of Education for funding this project (Fundamental Research Grant Scheme: FRGS/STWN01(04)991/2013(32)). They would also like to acknowledge Associate Professor Othman Bojo and Dr. Mohd Effendi bin Wasli for their assistance in identifying the aquatic plants.

\section{References}

[1] V. Papu-Zamxaka, A. Mathee, T. Harpham et al., "Elevated mercury exposure in communities living alongside the Inanda Dam, South Africa," Journal of Environmental Monitoring, vol. 12, no. 2, pp. 472-477, 2010.

[2] P. Maršálek, Z. Svobodová, and T. Randák, "Mercury and methylmercury contamination of fish from the Skalka reservoir: a case study," Acta Veterinaria Brno, vol. 74, no. 3, pp. 427434, 2005.

[3] L. Järup, "Hazards of heavy metal contamination," British Medical Bulletin, vol. 68, no. 1, pp. 167-182, 2003.

[4] S. E. Kakulu and O. Osibanjo, "Trace heavy metal pollution status in sediments of Niger Delta area," Journal of Chemical Society of Nigeria, vol. 13, pp. 9-11, 1988.

[5] J. O. Nriagu, "A silent epidemic of environmental metal poisoning?” Environmental Pollution, vol. 50, no. 1-2, pp. 139-161, 1988.

[6] R. Singh, N. Gautam, A. Mishra, and R. Gupta, "Heavy metals and living systems: an overview," Indian Journal of Pharmacology, vol. 43, no. 3, pp. 246-253, 2011.

[7] J. A. Arnot and F. A. P. C. Gobas, "A review of bioconcentration factor (BCF) and bioaccumulation factor (BAF) assessments for organic chemicals in aquatic organisms," Environmental Reviews, vol. 14, no. 4, pp. 257-297, 2006.

[8] S. A. Lawani and S. A. Alawode, "The use of fish for monitoring water pollution," Nigeria Journal of Biotechnology, vol. 4, pp. 5-7, 1987.

[9] B. C. O. Okoye, "Heavy metals and organisms in Lagos Lagoon," International Journal of Environmental Studies, vol. 37, pp. 285292, 1991.

[10] G. A. Obodo, "The accumulation of heavy metals in fish from lower reach of river Nigeria," Journal of Chemical Society of Nigeria, vol. 27, pp. 173-176, 2002.

[11] G. A. Obodo, "The bioaccumulation of heavy metals from fish Anambra River," Journal of Chemical Society of Nigeria, vol. 29, pp. 60-62, 2004.

[12] I. S. Eneji, R. Shaato, and R. A. Annune, "Bioaccumulation of heavy metals in fish (Tilapia zilli and Clarias gariepinus) organs from River Benue, North Central Nigeria," Pakistan Journal of Analytical Chemistry, vol. 12, pp. 25-31, 2011.

[13] C. A. Kelly, J. W. M. Rudd, R. A. Bodaly et al., "Increases in fluxes of greenhouse gases and methyl mercury following flooding of an experimental reservoir," Environmental Science and Technology, vol. 31, no. 5, pp. 1334-1344, 1997.

[14] R. A. Bodaly, V. L. St. Louis, M. J. Paterson et al., "Bioaccumulation of mercury in the aquatic food chain in newly flooded 
areas," in Mercury and Its Effects on Environment and Biology, H. Sigel and A. Sigel, Eds., pp. 259-287, Marcel Dekker, New York, NY, USA, 1997.

[15] N. Milenkovic, M. Damjanovic, and M. Ristic, "Study of heavy metal pollution in sediments from the Iron Gate (Danube River), Serbia and Montenegro," Polish Journal of Environmental Studies, vol. 14, no. 6, pp. 781-787, 2005.

[16] P. Avila-Pérez, M. Balcáza, G. Zarazúa-Ortega, I. BarcelóQuintal, and C. Díaz-Delgado, "Heavy metal concentrations in water and bottom sediments of a Mexican reservoir," Science of the Total Environment, vol. 234, no. 1-3, pp. 185-196, 1999.

[17] H. Ghrefat and N. Yusuf, "Assessing $\mathrm{Mn}, \mathrm{Fe}, \mathrm{Cu}, \mathrm{Zn}$, and $\mathrm{Cd}$ pollution in bottom sediments of Wadi Al-Arab Dam, Jordan," Chemosphere, vol. 65, no. 11, pp. 2114-2121, 2006.

[18] A. Pattle and P. F. Foster, "Sarawak's hydro projects-building a better future with renewable energy," IPENZ Proceedings of Technical Groups 37/1(LD).

[19] L. Nyanti, K. M. Hiii, A. Sow, I. Norhadi, and T. Y. Ling, "Impacts of aquaculture at different depths and distances from cage culture sites in batang Ai hydroelectric dam reservoir, Sarawak, Malaysia," World Applied Sciences Journal, vol. 19, no. 4, pp. 451456, 2012.

[20] M. Roulet, M. Lucotte, N. Farella et al., "Effects of recent human colonization on the presence of mercury in Amazonian ecosystems," Water, Air, and Soil Pollution, vol. 112, no. 3-4, pp. 297-313, 1999.

[21] M. Roulet, M. Lucotte, R. Canuel et al., "Increase in mercury contamination recorded in lacustrine sediments following deforestation in the Central Amazon," Chemical Geology, vol. 165, no. 3-4, pp. 243-266, 2000.

[22] M. R. Anderson, "Duration and extent of elevated mercury levels in downstream fish following reservoir creation," River Systems, vol. 19, no. 3, pp. 167-176, 2011.

[23] M. Barletta, A. J. Jaureguizar, C. Baigun et al., "Fish and aquatic habitat conservation in South America: a continental overview with emphasis on neotropical systems," Journal of Fish Biology, vol. 76, no. 9, pp. 2118-2176, 2010.

[24] S. J. Hamilton, K. J. Buhl, and P. J. Lamothe, "Selenium and other trace elements in water, sediment, aquatic plants, aquatic invertebrates and fish from streams in Southeastern Idaho near phosphate mining operation: June 2000," Final Report as Part of the USGS Western U.S. Phosphate Project, 2010.

[25] S. B. T. Sany, A. Salleh, A. H. Sulaiman, A. Sasekumar, M. Rezayi, and G. M. Tehrani, "Heavy metal contamination in water and sediment of the Port Klang coastal area, Selangor, Malaysia," Environmental Earth Sciences, vol. 69, no. 6, pp. 2013-2025, 2013.

[26] M. M. El Bouraie, A. A. El Barbary, M. M. Yehia, and E. A. Motawea, "Heavy metal concentrations in surface river water and bed sediments at Nile Delta in Egypt," Suoseura, vol. 61, no. 1, pp. 1-12, 2010.

[27] American Public Health Association, American Water Works Association (AWWA) and Water Environment Federation (WEF), Standards Methods for the Examination of Water and Wastewater, APHA, Washington, DC, USA, 20th edition, 1998.

[28] P. Sarojam, "Application note. Analysis of fish and seafoods with AAnalyst 800 atomic absorption spectrophotometer for trace metal contamination, in accordance with AOAC Methods 999.10 and 999.11," Perkin Elmer, 2009.

[29] J. Martin and M. Meybeck, "Elemental mass-balance of material carried by major world rivers," Marine Chemistry, vol. 7, no. 3, pp. 173-206, 1979.
[30] G. Muller, "Index of geoaccumulation in sediments of the Rhine River," GeoJournal, vol. 2, no. 3, pp. 108-118, 1969.

[31] D. L. Tomlinson, J. G. Wilson, C. R. Harris, and D. W. Jeffrey, "Problems in the assessment of heavy-metal levels in estuaries and the formation of a pollution index," Helgoländer Meeresuntersuchungen, vol. 33, no. 1-4, pp. 566-575, 1980.

[32] F. Vardar and M. Unal, "Aluminium toxicity and resistance in higher plants," Advances in Molecular Biology, vol. 1, pp. 1-12, 2007.

[33] Q. Zhao, S. Liu, L. Deng, S. Dong, and C. Wang, "Longitudinal distribution of heavy metals in sediments of a canyon reservoir in Southwest China due to dam construction," Environmental Monitoring and Assessment, vol. 185, no. 7, pp. 6101-6110, 2013.

[34] G. Klaver, B. van Os, P. Negrel, and E. Petelet-Giraud, "Influence of hydropower dams on the composition of the suspended and riverbank sediments in the Danube," Environmental Pollution, vol. 148, no. 3, pp. 718-728, 2007.

[35] I. Ismail and I. M. Saleh, "Analysis of heavy metals in water and fish (Tilapia sp.) samples from Tasik Mutiara, Puchong," The Malaysian Journal of Analytical Sciences, vol. 16, no. 3, pp. 346352, 2012.

[36] P. Porvari, "Mercury levels of fish in Tucuruí hydroelectric reservoir and in River Mojú in Amazonia, the the state of Para, Brazil," Science of the Total Environment, vol. 175, no. 2, pp. 109117, 1995.

[37] K. J. French, M. R. Anderson, D. A. Scruton, and L. J. Ledrew, "Fish mercury levels in relation to characteristics of hydroelectric reservoirs in Newfoundland, Canada," Biogeochemistry, vol. 40, no. 2-3, pp. 217-233, 1998.

[38] J. R. Ikingura and H. Akagi, "Total mercury and methylmercury levels in fish from hydroelectric reservoirs in Tanzania," Science of the Total Environment, vol. 304, no. 1-3, pp. 355-368, 2003.

[39] B. Liu, H. Yan, C. Wang et al., "Insights into low fish mercury bioaccumulation in a mercury-contaminated reservoir, Guizhou, China," Environmental Pollution, vol. 160, no. 1, pp. 109-117, 2012.

[40] P. Louchouarn, M. Lucotte, A. Mucci, and P. Pichet, "Geochemistry of mercury in two hydroelectric reservoirs in Quebec, Canada," Canadian Journal of Fisheries and Aquatic Sciences, vol. 50, no. 2, pp. 269-281, 1993.

[41] S. E. Thompson, C. A. Burton, and D. J. Quinn, Concentration Factors of Chemical Elements in Edible Aquatic Organisms, University of California, Lawrence Livermore Laboratory, Biomedical Division, Livermore, Calif, USA, 1972.

[42] K. G. S. Nirbadha, J. A. Liyanage, and M. O. Amarasinghe, "A preliminary study on the presence of heavy metalsin aquatic plants from a freshwater wetland at Kelaniya," in Proceedings of the 9th Annual Forestry and Environment Symposium, University of Sri Jayewardenepura, Sri Jayewardenepura Kotte, Sri Lanka, 2003.

[43] D. R. Khanal and A. P. Knight, "Selenium: its role in livestock health and productivity," The Journal of Agriculture and Environment, vol. 11, pp. 102-106, 2010.

[44] A. Ikem and J. Egilla, "Trace element content of fish feed and bluegill sunfish (Lepomis macrochirus) from aquaculture and wild source in Missouri," Food Chemistry, vol. 110, no. 2, pp. 301309, 2008.

[45] M. G. M. Alam, A. Tanaka, G. Allinson, L. J. B. Laurenson, F. Stagnitti, and E. T. Snow, "A comparison of trace element concentrations in cultured and wild carp (Cyprinus carpio) of Lake Kasumigaura, Japan," Ecotoxicology and Environmental Safety, vol. 53, no. 3, pp. 348-354, 2002. 
[46] A. G. Maule, A. L. Gannam, and J. W. Davis, "Chemical contaminants in fish feeds used in federal salmonid hatcheries in the USA," Chemosphere, vol. 67, no. 7, pp. 1308-1315, 2007.

[47] S. P. Canton and W. D. V. Derveer, "Selenium toxicity to aquatic life: an argument for sediment-based water quality criteria," Environmental Toxicology and Chemistry, vol. 16, no. 6, pp. 1255-1259, 1997.

[48] T. W. May, J. F. Fairchild, J. D. Petty et al., "An evaluation of selenium concentrations in water, sediment, invertebrates, and fish from the Solomon River Basin," Environmental Monitoring and Assessment, vol. 137, no. 1-3, pp. 213-232, 2008.

[49] T. Townsend, T. Tolaymat, K. Leo, and J. Jambeck, "Heavy metals in recovered fines from construction and demolition debris recycling facilities in Florida," Science of the Total Environment, vol. 332, no. 1-3, pp. 1-11, 2004.

[50] Y. Wang, S. Sikora, H. Kim, B. Dubey, and T. Townsend, "Mobilization of iron and arsenic from soil by construction and demolition debris landfill leachate," Waste Management, vol. 32, no. 5, pp. 925-932, 2012.

[51] W. Stumm and J. J. Morgan, Aquatic Chemistry: Chemical Equilibria and Rates in Natural Waters, John Wiley \& Sons, Hoboken, NJ, USA, 1996.

[52] FAO, "Compilation of legal limits for hazardous substances in fish and fishery products," Food and Agricultural Organization Circular, vol. 466, pp. 5-100, 1983.

[53] M. Osaki, S. Yamada, T. Ishizawa et al., "Mineral characteristics of the leaves of 166 plant species with different phylogeny in the temperate region," Plant Foods for Human Nutrition, vol. 58, no. 2, pp. 139-152, 2003.

[54] I. Michalak and K. Chojnacka, "The application of macroalga Pithophora varia Wille enriched with microelements by biosorption as biological feed supplement for livestock," Journal of the Science of Food and Agriculture, vol. 88, no. 7, pp. 11781186, 2008.

[55] A. A. Al-Homaidan, A. A. Al-Ghanayem, and A. H. Alkhalida, "Green algae as bioindicators of heavy metal pollution in Wadi Hanifah Stream, Riyadh, Saudi Arabia," International Journal of Water Resources and Arid Environments, vol. 1, no. 1, pp. 10-15, 2011.

[56] M. Roulet, M. Lucotte, A. Saint-Aubin et al., "The geochemistry of mercury in central Amazonian soils developed on the Alterdo-Chão formation of the lower Tapajos River Valley, Para state, Brazil," Science of the Total Environment, vol. 223, no. 1, pp. 1-24, 1998.

[57] M. T. Alp, O. Ozbay, and M. A. Sungur, "Determination of heavy metal levels in sediment and macroalgae (Ulva Sp. and Enteromorpha Sp.) on the Mersin coast," Ekoloji, no. 82, pp. 4755, 2012.

[58] N. S. Saad, R. Artanti, and T. Dewi, "Phytoremediation for rehabilitation of agricultural land contaminated by cadmium and copper," Indonesian Journal of Agriculture, vol. 4, no. 1, pp. 17-21, 2011.

[59] Geological Survey Professional Paper 713, Mercury in the Environment, United States Government Printing Office, Washington, DC, USA, 1970. 

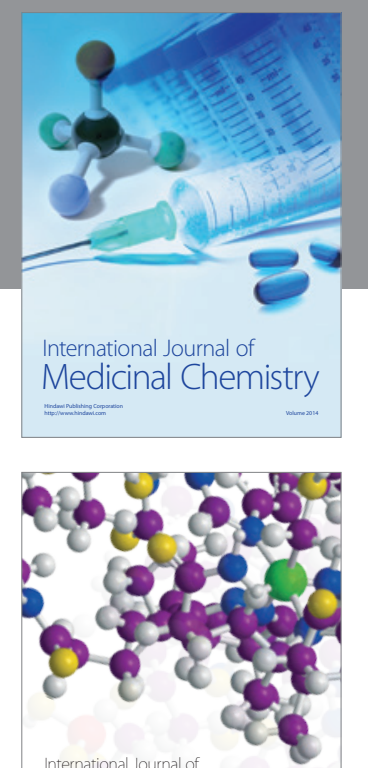

\section{Carbohydrate} Chemistry

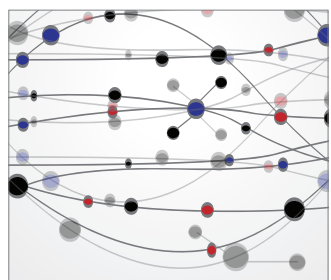

The Scientific World Journal
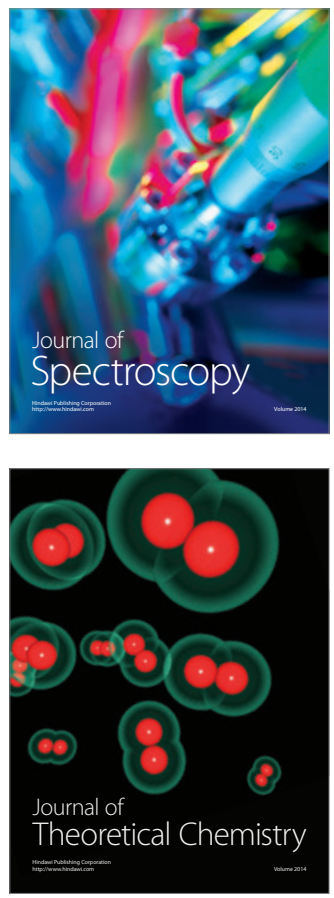
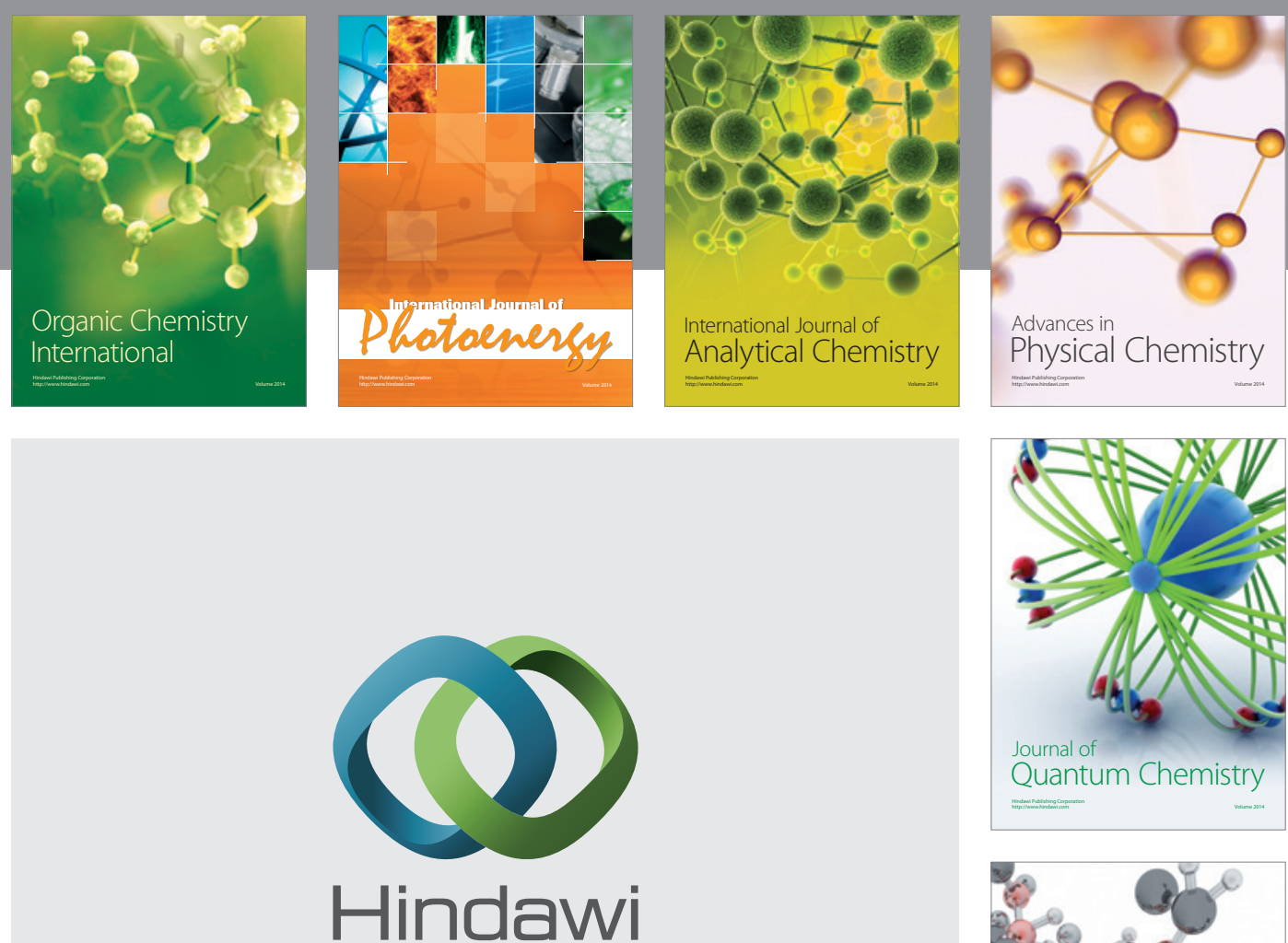

Submit your manuscripts at

http://www.hindawi.com

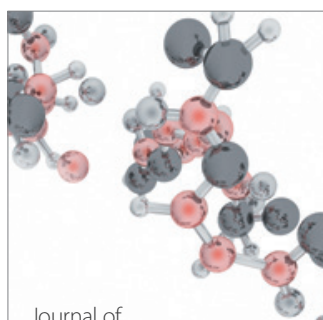

Analytical Methods

in Chemistry

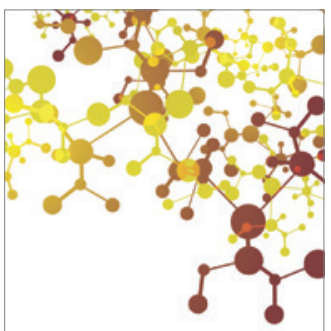

Journal of

Applied Chemistry

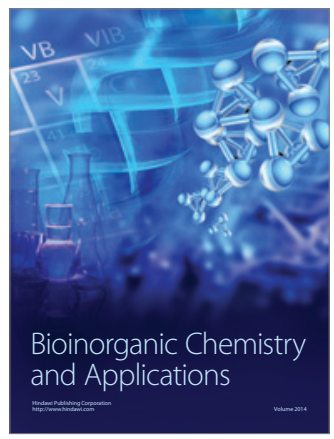

Inorganic Chemistry
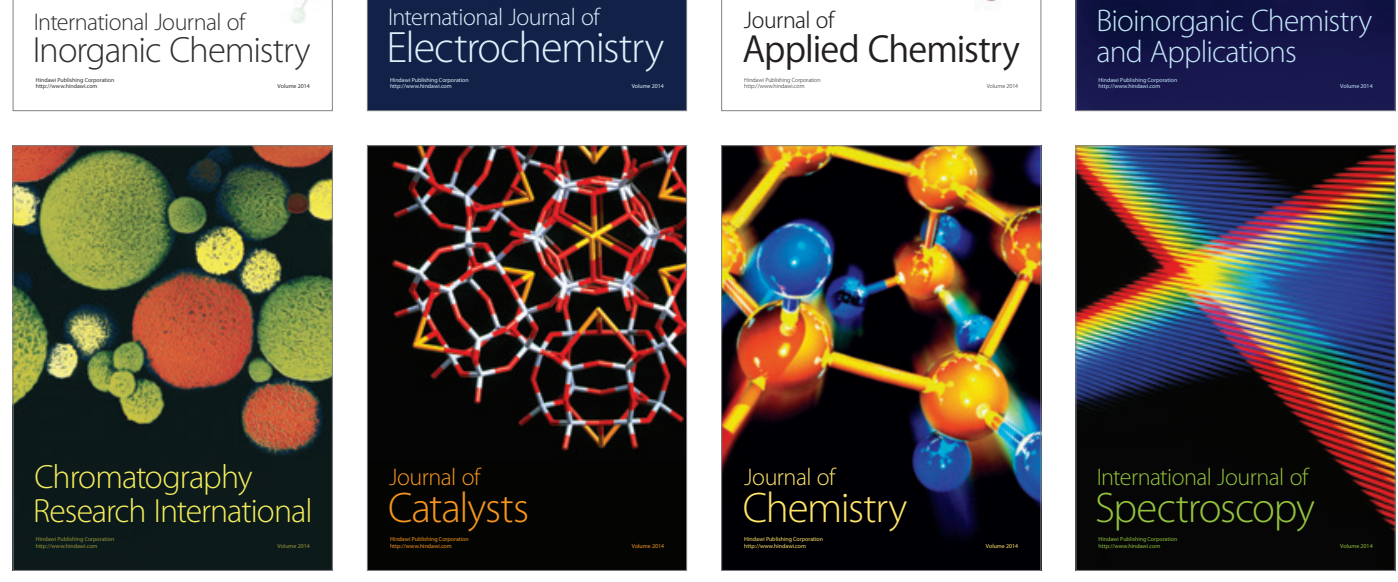